\title{
心臓ペースメーカー植込み患者における電磁波障害 一電気メスとマイクロ波メスー
}

$\begin{array}{llllll}\text { 山本 } & \text { 誠己, 田伏 克惇, 坂口 } \text { 雅宏, 下間 } \text { 仲裕 } \\ \text { 南 浩二, 長濱 } & \text { 実穂, 有井 一雄, 岡 } \text { 正巳 }\end{array}$

Electromagnetic Interference in Cardiac pacemakers. -Electrocautery and Microwave scalpel-

Seiki Yamamoto, Katsuyoshi Tabuse, Masahiro Sakaguchi, Nakahiro Shimotsuma

Kouji Minami, Miho Nagahama, Kazuo Ari and Masami Oka

\begin{abstract}
In Japan there are more than 15000 patients with cardiac pacemaker in a year. General surgical procedures in pacemaker patients have become common in recent years. General surgeon must have enough knowledge about surgical problem in pacemaker patients. It has been one of the important problem that the use of electrocautery sometimes interferes in the heart rhythm by pacemaker although there is no report, whether microwave scalpel has influence on the pacemaker rhythm or not. Recently we have alternately used electrocautery and new microwave scalpel (Blade type) on same patient during gastrectomy. In this paper, The influence of the electrocautery and microwave scalpel on the pacemaker function is reported respectively. It is demonstrated that a microwave scalpel has not influenced on the pacemaker rhythm as compared with electrocautery.
\end{abstract}

国立大阪南病院 - 外科

Department of Surgery, Osaka-Minami National Hospital

Key words: Microwave Tissue Coagulator (Blade type), Cardiac Pacemaker, Electromagnetic Interference. 
はじめに

心臓ペースメーカー植込み術は本邦において

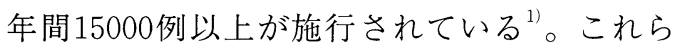
ペースメーカー植込み患者の一般外科手術を受 ける機会が増加している。それゆえ，一般外科 医もぺースメーカー植込み患者の手術について 十分な知識を持つ必要がある。特に電気メスの 使用は時にペースメーカーリズムに干渉するこ とがあり，一つの重要な問題とされている 2.3)。しかし, マイクロ波メスの心臓ペース メーカーへの影響についての報告はない。今 回, 著者らは胃癌手術に際して電気メスと従来 よりの止血機能に加えて切開機能を有する新型 マイクロ波メス (Blade 型電極) $)^{4)}$ を併用する機 会を得たので，電気メスとマイクロ波メスの心
臓ペースメーカーへの電磁波障害について比較 検討して報告する。

\section{対象と方法}

1980年より1991年12月までに表 1 のごとく 14例の心臓ペースメーカー植込み患者に対して 計16回の一般・消化器外科手術を施行した。そ の内訳は男性10例，女性 4 例で，年齢は47歳か ら88歳, 平均70.5歳であった。ペースメーカー 植込みから手術までの期間は 1 日から 3 年 9 ケ 月，平均15.2ケ月であった。手術対象となった 疾患は胃癌 4 例, 大腸癌 3 例, 胆囊癌 2 例, 肝 癌 1 例など全体の $60 \%$ は悪性腫瘍に対する手術 であった。以上の症例について電気メスとマイ クロ波メスの使用の有無と使用時のペースメー カーリズムへの影響について検討した。

表 1 心臟ペースメーカー植込み症例の一般・消化器外科手術例

\begin{tabular}{|c|c|c|c|c|c|c|}
\hline 症例 & 年令 & 性別 & $\begin{array}{c}\text { ペースメーカー植込みを } \\
\text { 必要とした心疾患 }\end{array}$ & $\begin{array}{c}\text { ペースメーカー } \\
\text { の 程 類 }\end{array}$ & 手術対象疾㭧 & 手術 々 式 \\
\hline 1 & 67 & $\delta$ & $\begin{array}{l}\text { Sick sinus } \\
\text { syndrome }\end{array}$ & 体内植込み型 & S 状結膓患 & S 状結腸切除術 \\
\hline 2 & 54 & $\delta$ & $\begin{array}{l}\text { Wolff-Parkinson } \\
\text { White 症候群 }\end{array}$ & 体内植込み型 & 䏣 石 症 & $\begin{array}{l}\text { 盟重墒出術 } \\
\text { 総䏣管ドレナージ術 }\end{array}$ \\
\hline 3 & 77 & $\delta$ & $\begin{array}{l}\text { Sick sinus } \\
\text { syndrome }\end{array}$ & 体内植込み型 & $\begin{array}{ll}\text { 盟 石 症 } \\
\text { 雷 }\end{array}$ & $\begin{array}{l}\text { 䏣衰墒出萧総䏣管ドレナージ術 } \\
\text { 骨全墒術 }\end{array}$ \\
\hline 4 & 57 & 우 & $\begin{array}{l}\text { 完全房室 } \\
\text { ブロック }\end{array}$ & 体 外 式 & 雷舟 & 盟全墒術 \\
\hline 5 & 78 & 우 & $\begin{array}{l}\text { 完全票室 } \\
\text { ブロック }\end{array}$ & 体内植込み型 & 甾腸我の腹壁穿孔 & ドレナージ術 \\
\hline 6 & 75 & ô & $\begin{array}{l}\text { 完全房室 } \\
\text { ブロック }\end{array}$ & 体 外 式 & 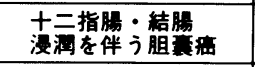 & $\begin{array}{l}\text { 胃腸吻合兼回腸横行結腸 } \\
\text { 吻合術 }\end{array}$ \\
\hline 7 & 53 & $\delta$ & $\begin{array}{l}\text { 完全房室 } \\
\text { ブロック }\end{array}$ & 体内植込み型 & $\begin{array}{ll}\text { 肝 } & \text { 癌 } \\
\text { 䏣 石 症 } \\
\end{array}$ & $\begin{array}{l}\text { 左菜切除術 } \\
\text { 䏣墒出術 } \\
\end{array}$ \\
\hline 8 & 47 & $\delta$ & $\begin{array}{l}\text { Sick sinus } \\
\text { syndrome }\end{array}$ & 体内植込み型 & 署普性イレウス & 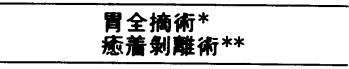 \\
\hline 9 & 79 & $\delta$ & $\begin{array}{l}\text { Sick sinus syndrome } \\
\text { 僧帽弁閉鎖不全症 }\end{array}$ & 体内植込み型 & 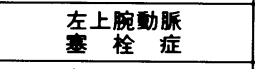 & 椣栓摘除術 \\
\hline 10 & 88 & $\delta$ & $\begin{array}{l}\text { 完全房室 } \\
\text { プロック }\end{array}$ & 体 外 式 & 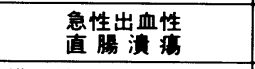 & 直腸切断術 \\
\hline 11 & 73 & 우 & $\begin{array}{l}\text { Sick sinus } \\
\text { syndrome }\end{array}$ & 体内植込み型 & 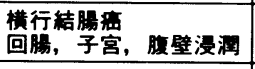 & $\begin{array}{l}\text { 右結腸切除術 } \\
\text { 子宮全摘, 回腸部分切除 }\end{array}$ \\
\hline 12 & 86 & $\delta$ & $\begin{array}{l}\text { 完全房室？ } \\
\text { ブロック？ }\end{array}$ & 体内植込み型 & 絞扼性イレウス & 回腸切除 \\
\hline 13 & 82 & $\delta$ & $\begin{array}{l}\text { 完全房室 } \\
\text { ブロック }\end{array}$ & 体内植込み型 & 呼吸不全 & $\begin{array}{l}\text { 気管切開 } \\
\text { 胃全墒術 }\end{array}$ \\
\hline 14 & 71 & 우 & $\begin{array}{l}\text { 徐脈性心房細钦 } \\
\text { 連合弁膜症 }\end{array}$ & 体内植込み型 & $\begin{array}{l}\text { 十三指腸漫潤を伴う } \\
\text { 䏣重癌 }\end{array}$ & $\begin{array}{l}\text { 䏣覆墒出術 } \\
\text { 胃指腸部分切除術 }\end{array}$ \\
\hline
\end{tabular}

*初回手術, **再手術 
表 2 電気メス, マイクロ波メスの使用について

\begin{tabular}{cccccc}
\hline & 使 用 頻 度 & ペースメーカーリズムへの干渉 \\
\hline 電気メス & $3 / 16$ 例 & $18.6 \%$ & $1 / 3$ 例 & $33.3 \%$ \\
マイクロ波メス & $2 / 16$ 例 & $12.5 \%$ & $0 / 2$ 例 & 0 & $\%$ \\
\hline
\end{tabular}

\section{結果}

電気メスの使用例は16例中症例 9，11，13の 3 例 $(18.6 \%)$ でその内 1 例（症例13）におい てペースメーカーへの干渉が認められた。マイ クロ波メスは肝切離に際して従来の針状型電極 を使用した症例 7 を含め 16 例中 2 例（症例 7 ,

13） $12.5 \%$ に使用したがペースメーカーへの干 渉はいずれも認められなかった（表 2 )。

\section{電気メスとマイクロ波のメスの}

closs over test を行えた症例（症例13）

患者症：82歳，男性

主 訴：呼吸困難, 貧血

家族歴：特記することなし。

既往歴：1986年完全房室ブロックのため心臓 ペースメーカー（VVI 型）植込み術を受け た。1990年脳梗塞のため左片麻痺となった。 1990年頃より慢性気管支炎として加療されてい た。

現病歴：1991年 5 月 1 日より発熱があり， 5 月 10日呼吸困難を伴うようになり当院循環器科に 入院，貧血がみられたため 5 月 17 日胃内視鏡検 查施行，胃癌と診断され 6 月 12 日外科に転科し た。

現 症: 栄養状態不良体格小, 血圧 138/ $72 \mathrm{mmHg}$ ，脈拍67/分，整（ペースメーカーリズ ム）緊張良好，心音純，呼吸音は粗糙で湿性ラ
音を聴取した。腹部は陥凹，軟，心窩部に腫瘤 を触知した。

検査成績：白血球増加, 軽度の貧血がみられた (表 3 )。

胸部 X線写真：右胸部にペースメーカーが植込 まれ，心陰影の拡大，慢性気管支炎の像がみら れた（図 1)。

胃 X 線検査：幽門部を中心に巨大な癌腫が存在 し，横隔膜を介してペースメーカーリードが胃 弓隆部に接しているのがみられた（図 2 )。 心電図所見：脈拍 $70 /$ 分前後の心室ペーシング リズムであった（図３）。

以上より 7 月 2 日全身麻酔下に胃全摘術を施 行した。

術中心電図変化：麻酔導入より手術開始直後は 術前同様のペースメーカーリズムであった (図 4 a)。電気メス使用によりペーシング不全 を若起し，自己リズムによる補充調律がみら れ，ままたセンシング不全もみられ，明らかに ペースメーカーリズムへの干渉が認められた (図 4 b)。そこでマイクロ波メスを使用し手術 を続行したが，マイクロ波メスはペースメー カーリズムにはまったく干渉しなかった (図 4 c)。約30分後にはA-V junctional rhythm と考えられる自己調律となった(図 $5 a$ )。そこ で再度電気メスを使用したところ，ペースメー カーリズムの誘発がみられ，自己調律とペース メーカーリズムが混在した状態となった (図 5 b)。マイクロ波メスはペースメーカーリ ズムと自己調律混在時にも影響を与えず (図 $5 \mathrm{c}$ ), それ以後マイクロ波メスのみを使用 して無事胃全摘術を終了した。 


\begin{tabular}{|c|c|c|c|c|}
\hline \multicolumn{2}{|l|}{$\mathrm{RBC}$} & $3.93 \times 10^{6} / \mu l \downarrow$ & TP & $6.3 \mathrm{~g} / \mathrm{d} \ell$ \\
\hline \multicolumn{2}{|l|}{$\mathrm{Hb}$} & $11.8 \mathrm{~g} / \mathrm{d} \ell \downarrow$ & ALB & $4.0 \mathrm{~g} / \mathrm{d} \ell$ \\
\hline \multicolumn{2}{|l|}{$\mathrm{Ht}$} & $35.9 \%+$ & T-Bil & $0.63 \mathrm{mg} / \mathrm{dl}$ \\
\hline \multicolumn{2}{|l|}{ PLT } & $21.4 \times 10^{4} / \mu l$ & D-Bil & $0.25 \mathrm{mg} / \mathrm{d} \ell$ \\
\hline \multicolumn{2}{|l|}{ WBC } & $12.9 \times 10^{3} / \mu l \uparrow$ & GOT & $15 \mathrm{mU} / \mathrm{ml}$ \\
\hline \multicolumn{2}{|l|}{ Stab } & $24.0 \%$ & GPT & $9 \mathrm{mU} / \mathrm{ml}$ \\
\hline \multicolumn{2}{|l|}{ Seg } & $55.0 \%$ & $\mathrm{LDH}$ & $322 \mathrm{mU} / \mathrm{ml}$ \\
\hline \multicolumn{2}{|l|}{ Eo } & $4.0 \%$ & $\mathrm{CH}-\mathrm{E}$ & $0.28 \Delta \mathrm{pH}+$ \\
\hline \multicolumn{2}{|l|}{ Lym } & $11.0 \%$ & $A L P$ & $168 \mathrm{mU} / \mathrm{ml}$ \\
\hline \multicolumn{2}{|l|}{ Mo } & $5 \%$ & $\gamma$-GTP & $28 \mathrm{mU} / \mathrm{ml}$ \\
\hline \multirow{2}{*}{\multicolumn{2}{|c|}{ Meta }} & $1.0 \%$ & LAP & $40 \mathrm{mU} / \mathrm{ml}$ \\
\hline & & & Amylase & $83 \mathrm{mU} / \mathrm{ml}$ \\
\hline \multicolumn{2}{|c|}{ Bleeding time } & $1 \mathrm{~min} 30 \mathrm{sec}$. & $\mathrm{CPK}$ & $32 \mathrm{mU} / \mathrm{ml}$ \\
\hline \multicolumn{2}{|l|}{ PT } & $12.2 \mathrm{sec} .80 \%$ & $\mathrm{Ca}$ & $10.07 \mathrm{mg} / \mathrm{d} \ell$ \\
\hline \multicolumn{2}{|l|}{ APTT } & $41.6 \mathrm{sec}$ & BUN & $36.8 \mathrm{mg} / \mathrm{d} \ell \uparrow$ \\
\hline \multicolumn{2}{|c|}{ Fibrinogen } & $337 \mathrm{mg} / \mathrm{dl}$ & Creatinine & $1.05 \mathrm{mg} / \mathrm{d} \ell$ \\
\hline \multicolumn{2}{|c|}{ Thrombo test } & $60 \%$ & B·Sugar & $112 \mathrm{mg} / \mathrm{dl}$ \\
\hline \multirow{2}{*}{\multicolumn{2}{|c|}{ Hepaplastin test }} & $57 \%$ & $\mathrm{Na}$ & $141 \mathrm{mEq} / \mathrm{L}$ \\
\hline & & & $\mathrm{K}$ & $5.0 \mathrm{mEq} / \mathrm{L}$ \\
\hline \multirow{2}{*}{\multicolumn{3}{|c|}{ 尿検查＼cjkstart正常 }} & $\mathrm{Cl}$ & $105 \mathrm{mEq} / \mathrm{L}$ \\
\hline & & & $\mathrm{Fe}$ & $61 \mu \mathrm{g} / \mathrm{d} \ell \downarrow$ \\
\hline \multicolumn{3}{|c|}{ 血液ガス分析 } & TIBC & $193 \mu \mathrm{g} / \mathrm{d} \ell \downarrow$ \\
\hline $\mathrm{PH}$ & \multicolumn{4}{|c|}{7.416} \\
\hline $\mathrm{PCO}_{2}$ & \multicolumn{2}{|c|}{$38.8 \mathrm{mmHg}$} & CEA & $2.6 \mathrm{ng} / \mathrm{ml}$ \\
\hline $\mathrm{PO}_{2}$ & \multicolumn{2}{|c|}{$89 \mathrm{mmHg}$} & CA $19-9$ & $11.5 \mathrm{U} / \mathrm{ml}$ \\
\hline $\mathrm{HCO}_{3}^{-}$ & \multicolumn{2}{|c|}{$25.2 \mathrm{mmol} / \mathrm{l}$} & & \\
\hline$B E$ & \multicolumn{2}{|c|}{$0.4 \mathrm{mmol} / \mathrm{l}$} & & \\
\hline$\%{ }_{s} \mathrm{O}_{2 \mathrm{c}}$ & \multicolumn{2}{|c|}{$97.0 \%$} & & \\
\hline
\end{tabular}

\section{考察}

心臓ペースメーカー植込み術は本邦において 年間 15000 例以上が施行されており，それら ペースメーカー植込み患者が一般外科手術を受 ける機会も増加している ${ }^{3,5,6)}$ 。最近の手術室に おいてはモニター類をはじめ多数の電気医療器
機が使用され，医療器機間の電磁波障害が一つ の重要な問題となってきている。特に心臓ぺー スメーカーへの電磁波障害はモニター類への障 害と異なり患者の生命に直接的に影響を与える ため，より慎重な検討が必要である7”。電気メ スの心臓ペースメーカーへの電磁波障害は患者 の状態, ペースメーカーの種類, 手術部位, 電 


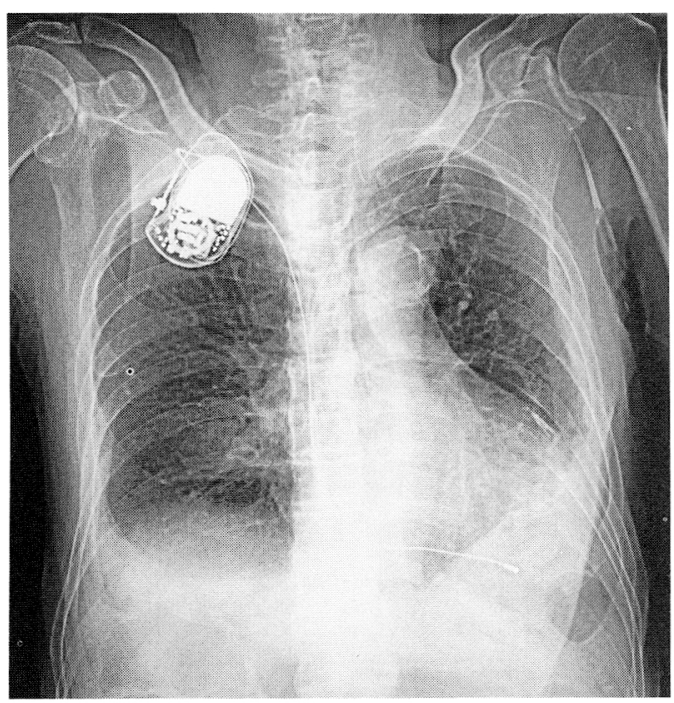

図 1 胸部X線写真

右胸部にペースメーカーが植込まれ，心㓌影の 拡大，慢性気管支炎の像がみられる。

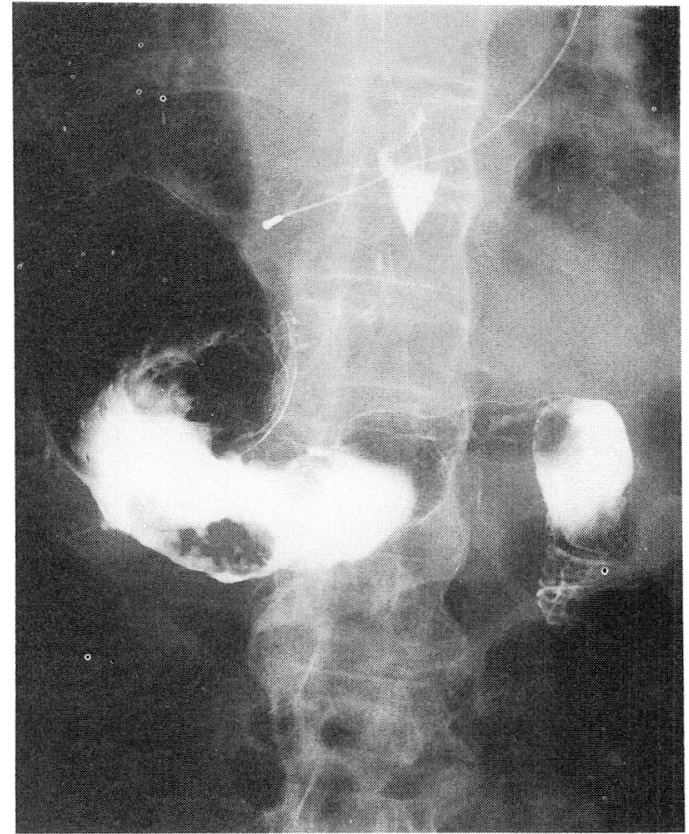

図 2 胃X線検査

幽門部に㓌影欠損がみられ，横隔膜を介して ペースメーカーリードが胃引隆部に接している。

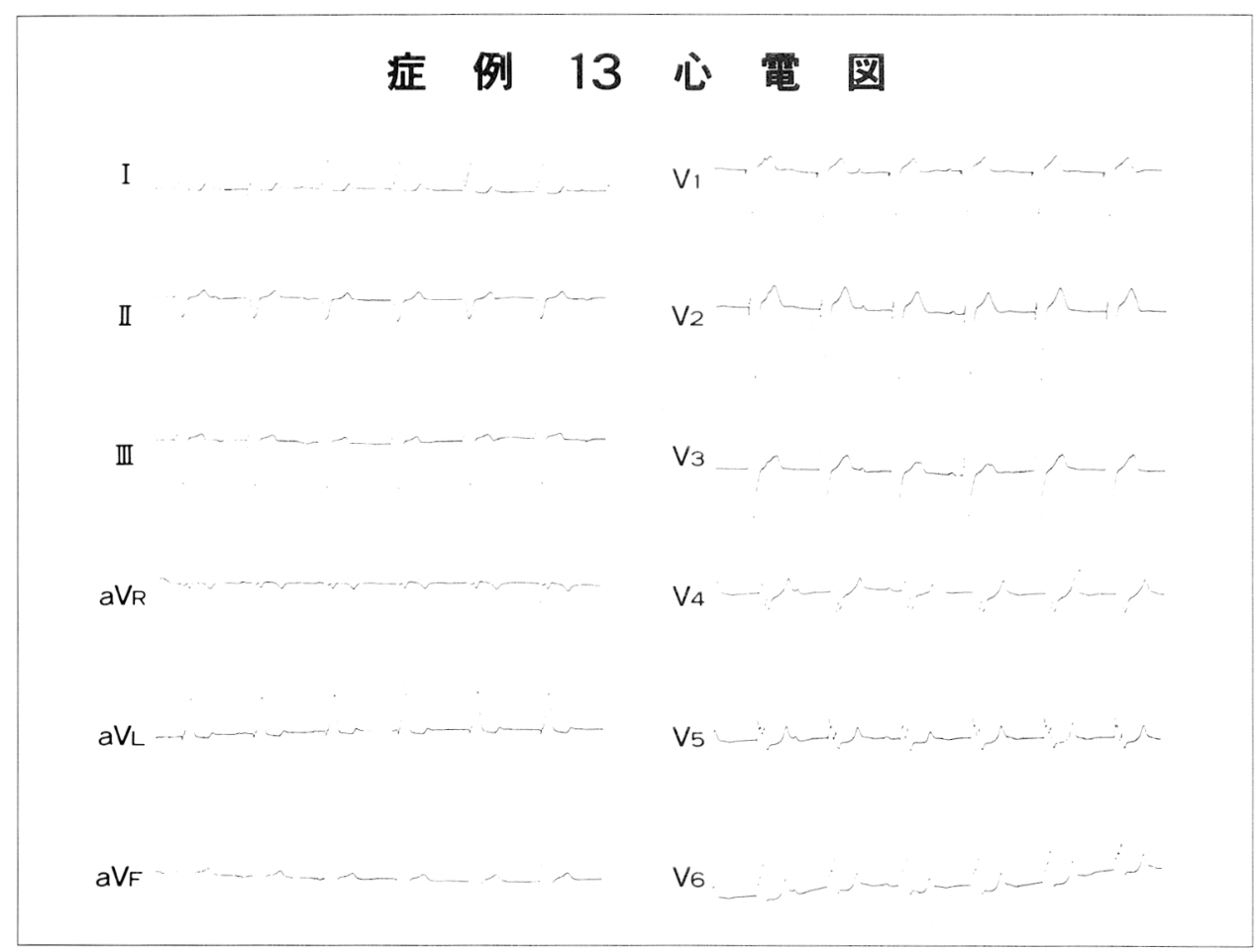

図 3 脈拍70/分前後の心室ペーシングリズムである。 


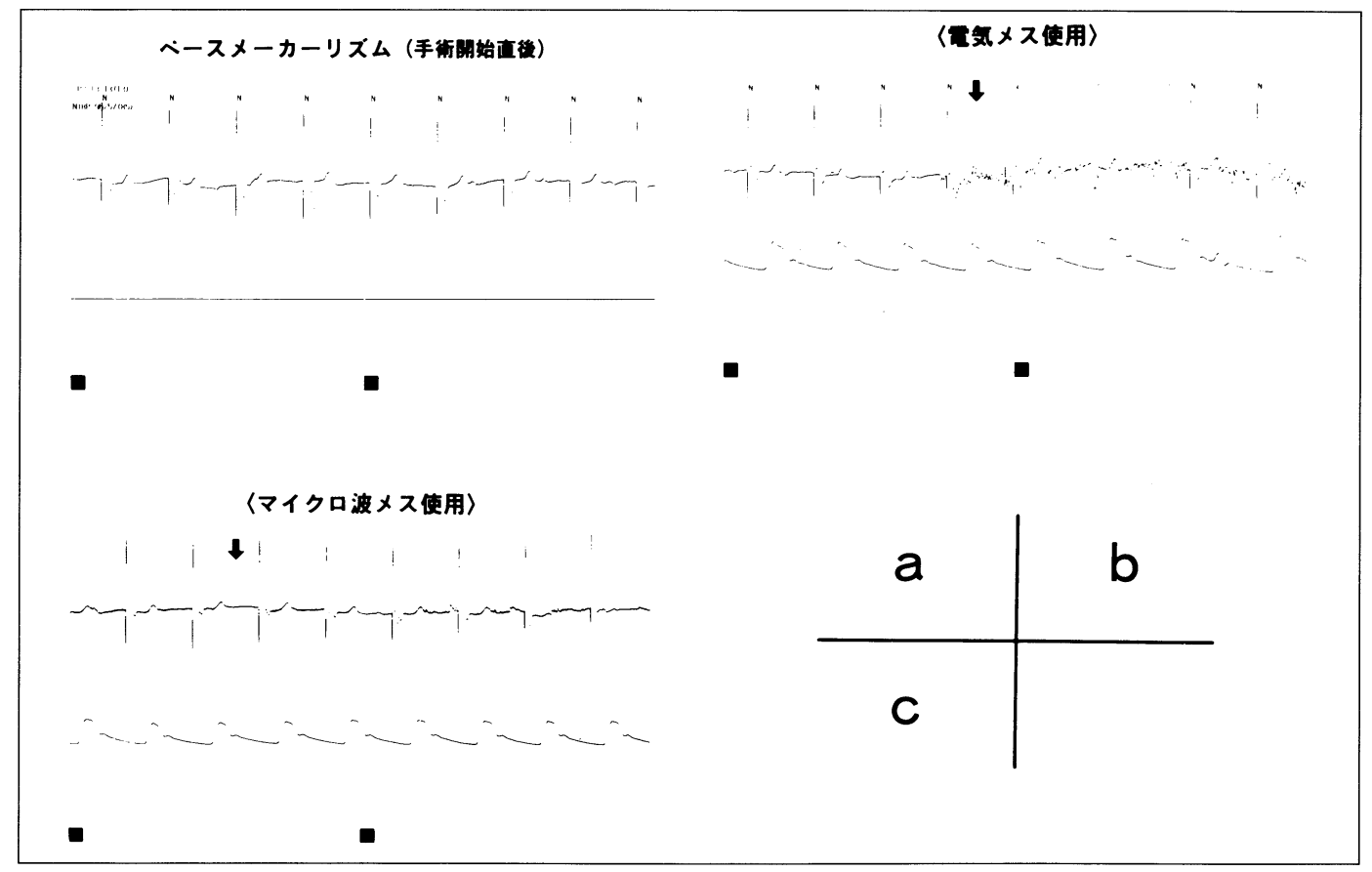

図 4 術中心電図 1

電気メスの使用はペースメーカーリズムに干渉したがマイクロ波メスの使用による影響は見られなかった。

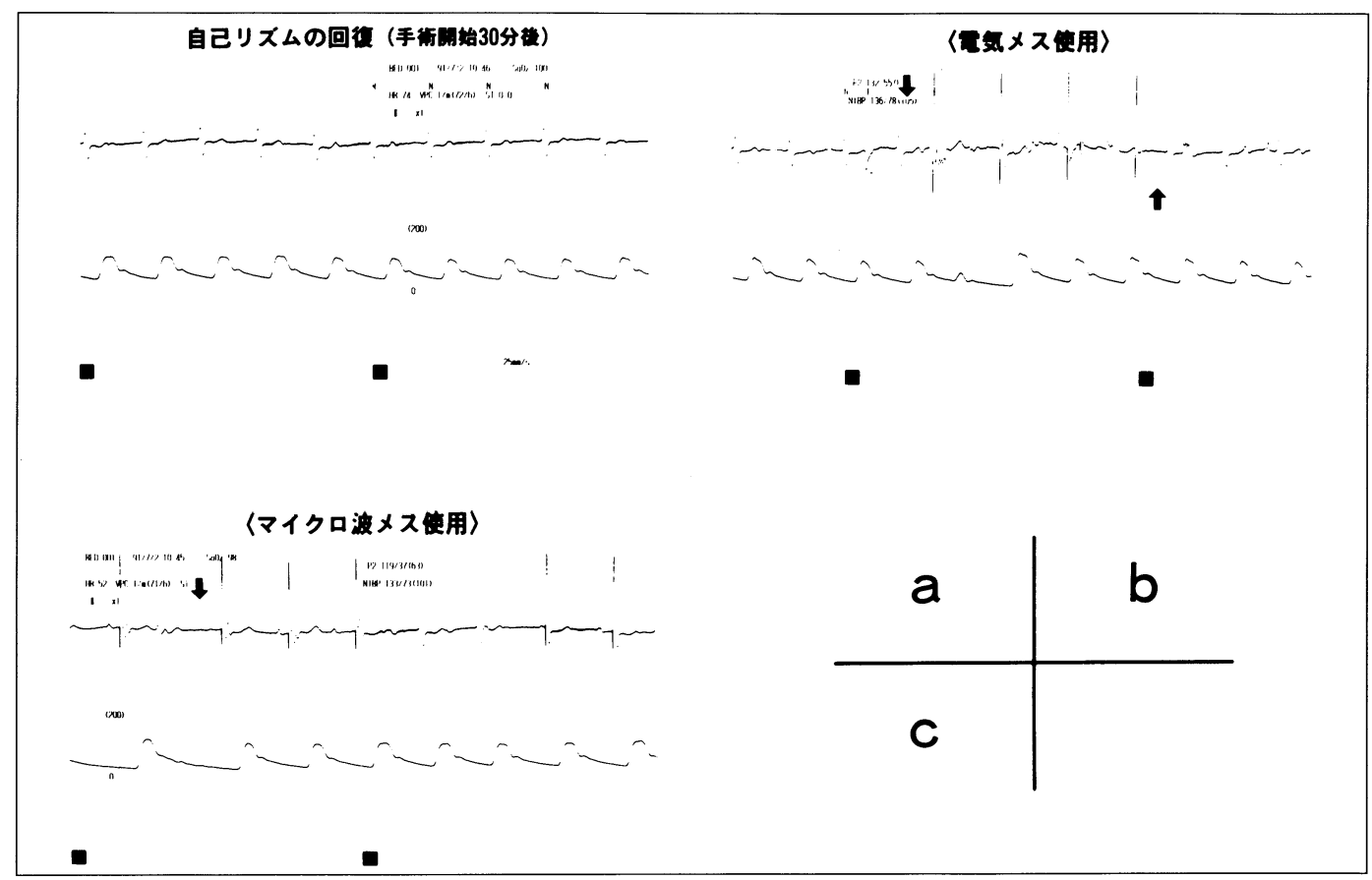

\section{図 5 術中心電図 2}

術中自己リズムの回復が見られ，再度電気メスを使用したところペースメーカーリズムの誘発がみられた。 マイクロ波メスはペースメーカーリズムと自己調律混在時にも干渉しなかった。 
気メスの種類，対極板の部位などにより全例に みられるわけではない。著者らも電気入ス使用 例 3 例中 1 例にペースメーカーへの干渉がみら れたのみであった。しかし，時に心室頻拍，心 停止, RonT の出現など重篤な病態を若起する ことが報告されている

今回使用した電気メスは放電熱を，マイクロ 波メスは内部誘電加熱を手術に利用するもので あるが，その周波数は電気メスでは数 $100 \mathrm{KHz}$ ～数 $\mathrm{MHz}$ の短波であり，一方マイクロ波メスは $2450 \mathrm{MHz}$ の極超短波であるので誘電物質に対す る電磁波の伝わり方や電界の与え方が異なる ${ }^{12)}$ 。 電気入スの電磁波の波長は100 $1000 \mathrm{~m}$ と長い ので高周波電流の帰路として対極板を必要と し，電気メス先端電極と対極板の間の人体に電 流が広く流れることになり，心蔵ペースメー カーへの干涉の可能性も当然高くなる。電気入 ス使用時における心臟ペースメーカーへの電磁 波障害の原因として，低周波漏れ電流，メス先 電極と生体との間の整流作用によって生じた直 流成分や，電気メスの高周波電流が直接ペース メーカーに流れ込むことによるもの，電気メス 使用によりペースーメーカーリードに生ずる誘 起電圧による障害などがあげられている ${ }^{11)} 。$ 般的にはほとんどの心臓ペースメーカーには電 磁波障害保護機構が備わっており，それらの電 磁波に対してシールドされているはずである が，時に電気メス使用がペースメーカーに障害 を与えた場合にはペースメーカー側からは二通 りの変化が考えられる。第一は電磁波障害保護 機構が働き，マグネットレートと言われる固定 レートとなる。第 2 にはペースメーカー器械自 体に損害を与えた場合で，損害個所によりマグ
ネットレートになるか, 最悪の場合にはペーシ ング停止になるといわれている ${ }^{13)}$ 。しかし, 複 雑なセンシング機構のある最近のペースメー カーに抢いては著者らの症例のようにセンシン グ不全を主とする障害もある。原則として心臟 ペースメーカー患者の手術に際しては電気メス の使用は好ましくなく，もし使用する際には次 のような点に注意して使用すべきである。(1)連 続使用しない（2３秒以内)。(2)植込まれた ペースメーカーおよびリードからできるかぎり 離して使用する。(3)サージカルユニットと対極 板との間のコードとペースメーカーの電極コー ドとは垂直にする。(4)対極板はペースメーカー から離し, 術野に近い位置に貼る。(5)出力を下 げるなどの注意点が指摘されている ${ }^{14)}$ 。

マイクロ波も同じ高周波であるためマイクロ ウェーブオーブンなどによる心蔵ペースメーカーヘ の電磁波障害は古くから報告されている ${ }^{15,16)}$ 。

しかし，現在使用されているマイクロ波メス の心臓ペースメーカーへの影響についての報告 はなく，今回の著者らの同一患者での cross over test の報告が最初である。著者らの経験 では針状電極型, 新型メス (blade 型電極) と もマイクロ波メスの使用は心臟ペースメーカー に対して影響しなかった。これはマイクロ波メ スは電磁波の波長が $12 \mathrm{~cm}$ と極めて短く, 電気メ スのようにメス先電極と対極板との間の人体に 広範囲に電流が流れるのではなく，マイクロ波 メス先の限局された部分にのみしか電磁界はな く，また吸収されてしまうという特徵があるた め, 一定の距離を扔いて使用する際には心臓 ペースメーカーには影響しないものと考えられ る。しかし, 温熱治療器によりマイクロ波を照 
射されたため, ペースメーカー機能が停止した との報告もあるが ${ }^{17)}$, 照射された電界内にペー スメーカー本体が存在する場合にのみ生じるも のであり，マイクロ波メスのように電磁界を集 束，限局して使用するように設計されている場 合には問題とはならない。しかし, 胸部の手術 などでペースメーカー本体に接近してマイクロ 波メスを使用する場合には, 電磁波障害を若起 する可能性も否定し得ず注意して使用すべきで ある。

\section{おわりに}

心蔵ペースメーカー植込み患者に対する一般 外科手術に㧍ける電気メスとマイクロ波メスの 電磁波障害について著者らの経験を中心に若干 の文献的考察を加えて報告した。

\section{文献}

1）桜井靖久：成熟した治療技術 モダンメディシ ン, $89: 83-86,1989$ 。

2) Erdman, S., Levinsky, L., Servadio, C., Stoupel, E., Levy, M. J. : Safety precautions in the management of patients with pacemakers when electrocautery operations are performed Surg Gynecol Obstet., $167: 312-314,1988$.

3 ) Levine, P. A., Balady, G. J., Lazar, H. L., Belott, P. H., Roberts, A. J. : Electrocautery and pacemakers. Management of the paced patient subject to electrocautery Ann Thorac Surg., $41: 313-317$, 1986.

4 ) 田伏克惇, 山本誠己, 坂口雅宏, 下間仲裕：Microwave 新型メス (blade 型電極)を用いた外科手術.

日本医事新報, $3557: 37-40,1992$ 。

5 ）黑河内信夫, 清野誠一: ペースメーカーと麻酔.

臨床麻酔, $10: 717-783,1986$ 。

6 ) 須藤峻章, 菖蒲隆治, 金沢秀剛, 椿本龍次, 藤井 芳郎, 河村正生, 笠原 洋, 梅村博也, 白羽
誠, 久山健, 西岡孝純, 奥 秀喬, 城谷 均: ペーシング下における開腹手術. Arch Jpn Chir., 55 : 597-608, 1986。

7 ) 豊島 健：心臓ペースメーカーの電磁障害. 心蔵 ペーシング, $4: 276-287,1988$ 。

8 ）表 哲夫, 並木昭義, 土肥修司, 高橋長雄, 大堀 克己：ペースメーカー植込み術中電気メス使用に より心停止をきたした 1 症例. 麻酔, 10 : 11261129,1981 。

9 ) 粟野知子, 木山秀哉, 小山 薰, 長沢誠一郎 : 電 気メスによりRonTがみられたペースメーカー使 用例. 臨床麻酔, $9: 181-183,1985$ 。

10）木村智政, 山下晃史, 後藤康之: 電気入ス使用に よりペースメーカー干渉をきたした 1 症例. 臨床 麻酔，9:1353-1356，1985。

11）志賀達哉, 後藤文夫 : 佔外式ペーシング中, 電気 メス使用によりみられた心律動異常. 臨床麻酔, $10: 259-261,1986$ 。

12）銭谷利男：マイクロ波の誘電加熱とマイクロ波手 術器の安全対策. J. Microwave Surg., 6:3-13, 1988 。

13）川田光三, 早川誠悟 : ペースメーカー中の電気メ 又使用 Clinician, 32 :649-651，1985。

14）山村茂樹, 神谷和男, 林 睦子, 伊藤祐輔 : ペー スメーカー装着者の麻酔管理 一電気メスの使用 について一. 北陸麻酔誌, $24: 47-51,1990$ 。

15) King, G. R. : Effect of microwave oven on implanted cardiac pacemaker. JAMA, 212:1213, 1970.

16) Bonny, C. H., Rustan, P. L., Ford, G. E. : Evaluation of effects of the microwave oven (915 and 2450 $\mathrm{MHz})$ and radar $(2810$ and $3050 \mathrm{MHz})$ electromagnetic radiation on noncompetitive cardiac pacemakers. IEEE Trans Biomed Eng., $20: 357-$ 364, 1973.

17）会田 博, 清水 健, 坂本 滋, 白川尚哉, 金戸 善之, 豊田恒良, 志波知彦: 極超短波による $\mathrm{EMI}$ (Electromagnetic interference) のため作動停止し たペースメーカー症例の検討.人工臓器, 17 : 1192-1195, 1988。 